SAND2001-2476

Unlimited Release

Printed September 2001

\title{
Sandia University Research Program: An
} Evaluation

\section{Santa Falcone}

School of Public Administration

University of New Mexico

Albuquerque, NM 878131-1216

\section{Prepared for}

Sandia National Laboratories

Albuquerque, New Mexico 87185 and Livermore, California 94550

Sandia is a multi-program laboratory operated by Sandia Corporation, A Lockheed Martin Company, for the United States Department of Energy under Contract DE-AC04-94AL85000.

Originator: Santa Falcone Date: 10 September 2001

\section{Sandia National Laboratories}


Issued by Sandia National Laboratories, operated for the United States Department of Energy by Sandia Corporation.

NOTICE: This report was prepared as an account of work sponsored by an agency of the United States Government. Neither the United States Government, nor any agency thereof, nor any of their employees, nor any of their contractors, subcontractors, or their employees, make any warranty, express or implied, or assume any legal liability or responsibility for the accuracy, completeness, or usefulness of any information, apparatus, product, or process disclosed, or represent that its use would not infringe privately owned rights. Reference herein to any specific commercial product, process, or service by trade name, trademark, manufacturer, or otherwise, does not necessarily constitute or imply its endorsement, recommendation, or favoring by the United States Government, any agency thereof, or any of their contractors or subcontractors. The views and opinions expressed herein do not necessarily state or reflect those of the United States Government, any agency thereof, or any of their contractors.

Printed in the United States of America. This report has been reproduced directly from the best available copy.

Available to DOE and DOE contractors from

U.S. Department of Energy

Office of Scientific and Technical Information

P.O. Box 62

Oak Ridge, TN 37831

Telephone: (865)576-8401

Facsimile: (865)576-5728

E-Mail: reports@adonis.osti.gov

Online ordering: hup:/www.osti.gov/hridge

Available to the public from

U.S. Department of Commerce

National Technical Information Service

5285 Port Royal Rd

Springfield, VA 22161

Telephone: (800)553-6847

Facsimile: (703)605-6900

E-Mail: orders(antis.fedworld.gov

Online order: hup://www. ntis gov/help/ordermethods asp?loc=7-4-()\#online

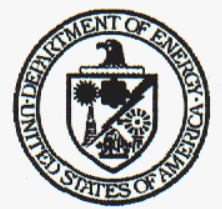




\title{
SAND2001-2476 \\ Unlimited Release \\ Printed August 2001
}

Sandia University Research Program: An Evaluation

\author{
Santa Falcone \\ School of Public Administration \\ University of New Mexico \\ Albuquerque, NM 87131-1216 \\ falcone@,unm.edu
}

Abstract 
•

, 


\section{Contents}

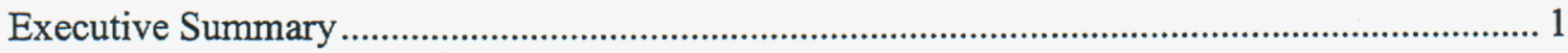

Program Evaluation Description............................................................................................. 2

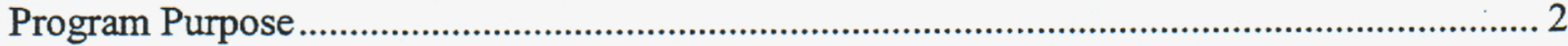

Program Evaluation Purpose................................................................................................. 2

Program Evaluation Method .............................................................................................. 2

PART I: PROGRAM CHARACTERISTICS ...................................................................... 3

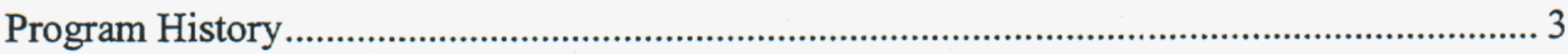

Program Comparisons......................................................................................................... 3

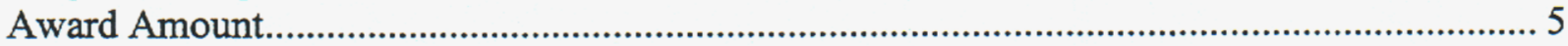

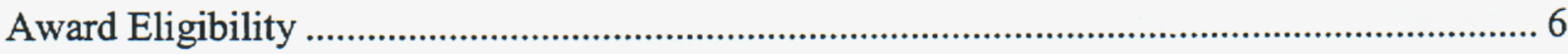

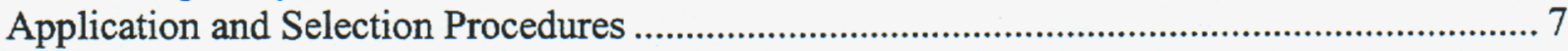

Scientific Competence ............................................................................................................ 7

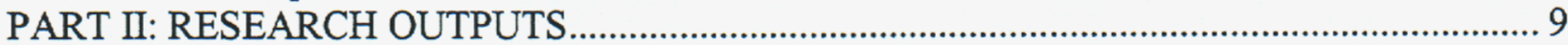

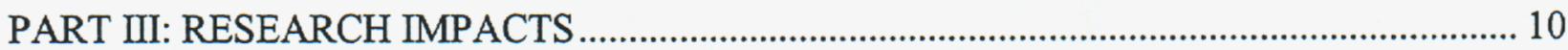

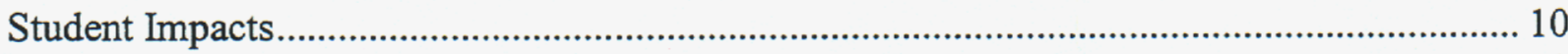

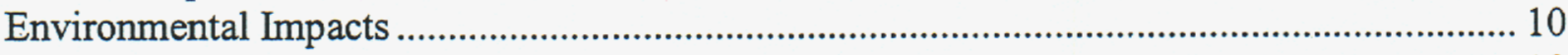

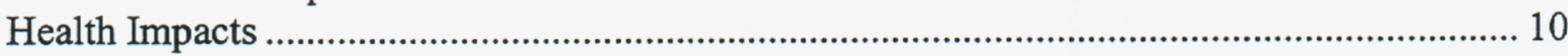

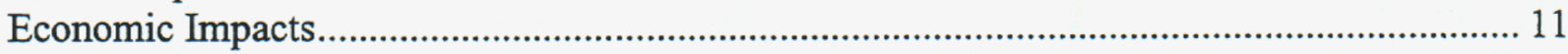

Principal Investigator Career Impacts.................................................................................... 12

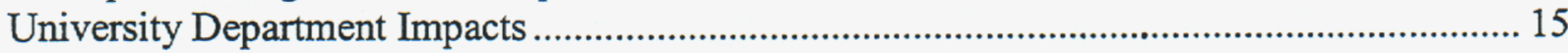

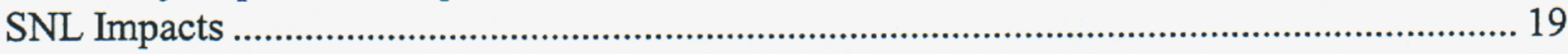

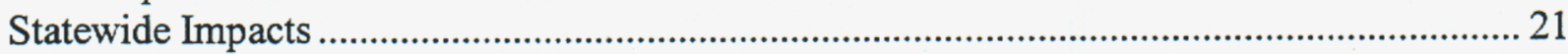

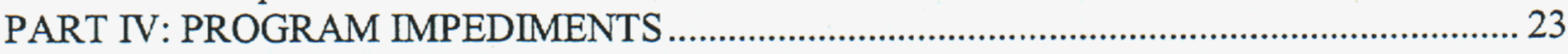

PART V: EVALUATION SUMMARY AND RECOMMENDATIONS ……………………..... 25

Figures

Figure 1. Annual Total SURP Funding 1990-1997 .................................................................... 3

\section{Tables}

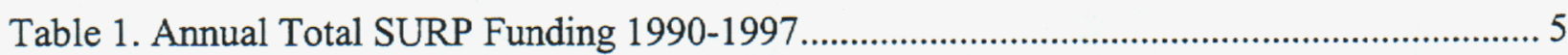

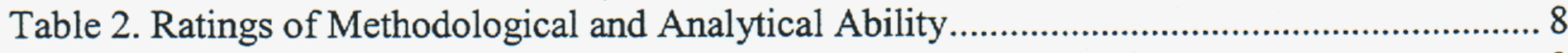

Table 3. Research Output...................................................................................................... 9

Table 4. Student Participation.................................................................................................. 10

Table 5. Subsequent Research Grants/Contracts/Projects Resulting from SURP Research. Listed by Follow-on Funding Source............................................................................... 15

Table 6. SURP Project Outputs Applicable to Defense Programs ................................................ 19

Table 7. Linkages of SURP projects to SNL Foundations/Competencies/Missions ..................... 20

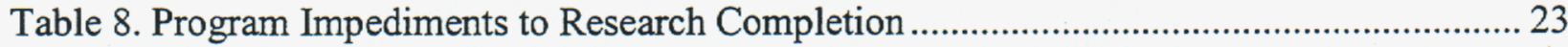

Table 9. Factors Impeding Collaboration ………….................................................................... 24 
, 


\section{Executive Summary}

The Sandia University Research Program (SURP) program is achieving its purpose. According to the varied professional perspectives of the respondents to an evaluation survey, SURP effectively supports the professional development of new science and engineering faculty at New Mexico's universities. Departments, colleges, and the universities indirectly benefit as SURP recipients continue in productive academic careers. While the consensus regarding SURP is positive, this report discusses suggestions for improvements in the areas of award eligibility, financial considerations, and alignment of research interests. These improvements will further enhance the strengths of this program. 


\section{Program Evaluation Description}

\section{Program Purpose}

Reflecting the federal government's policy of supporting universities in order to maintain high standards of research and development in fields of study crucial to the national interest, Sandia National Laboratories (SNL) established the Sandia University Research Program (SURP) in 1958. The purpose of SURP is twofold:

1. to acquire fundamental knowledge in those technical fields which are of direct concern to Sandia National Laboratories' programs; and

2. to create a stronger technical community at universities in New Mexico with which Sandia National Laboratories can interact through strengthening university faculties in areas of science and engineering important to Sandia National Laboratories ${ }^{1}$.

To accomplish this purpose, then and now, SNL provides research funds for new faculty (or new initiatives in technical fields of direct interest to SNL) at New Mexico universities.

\section{Program Evaluation Purpose}

This report discusses an evaluation designed to determine if SURP is fulfilling its purpose to SNL and New Mexico's universities.

\section{Program Evaluation Method}

The evaluation team obtained the data presented in this report through both phone and face-toface interviews, using a survey instrument developed for this research, and searches of archived files and published paper and electronic documents. The survey sample included both past and present administrators of SURP at SNL and the three universities currently participating in SURP (University of New Mexico [UNM], New Mexico State University [NMSU], and New Mexico Institute of Mining and Technology [NMT]); university department heads with faculty who receive SURP awards; SNL contacts for SURP awards; and faculty SURP recipients.

In choosing the faculty recipients for this survey, the administrators at UNM, NMSU, and NMT each selected one recipient who received the award at least five years prior to this study and a second recipient who received the award within the past two years. The two recipients represented two different academic disciplines. The evaluators interviewed the SNL contacts who mentored the selected SURP recipients.

Of the 52 administrators and faculty contacted, 50 participated in the study. The evaluation team coded the responses for entry into both EXCEL and SAS. Summaries and examples of the qualitative responses are included in the report.

${ }^{1}$ Letter from Paul Fleury to Lyle E. Whelchel, August 26, 1993. 


\section{PART I: PROGRAM CHARACTERISTICS}

\section{Program History}

The SURP program began in 1958 during the tenure of SNL president James MacRae. From 1958 to 1997, SNL requested proposals for research projects from new professors or new initiatives in technical fields of direct interest to SNL at Ph.D.-granting institutions in the state of New Mexico. UNM, geographically the closest to SNL, was the most active participant throughout this period. NMT and NMSU have become more active in the past two decades. SNL funded approximately five projects at $\$ 20,000$ each in the late 1950's and early 1960's. Inflation brought the number of projects funded down to three or four per year until the total amount of funding available was raised in the $1970{ }^{\prime} \mathrm{s}^{1}$. With more funds available, SURP accepted from 8 to 20 projects each year. The award amount was raised to $\$ 30,000$ per project in the 1980 s and in 1993 increased to the present $\$ 35,000$ per project $^{2}$. Figure 1 indicates the level of participation of New Mexico universities in this program from 1990-1997.

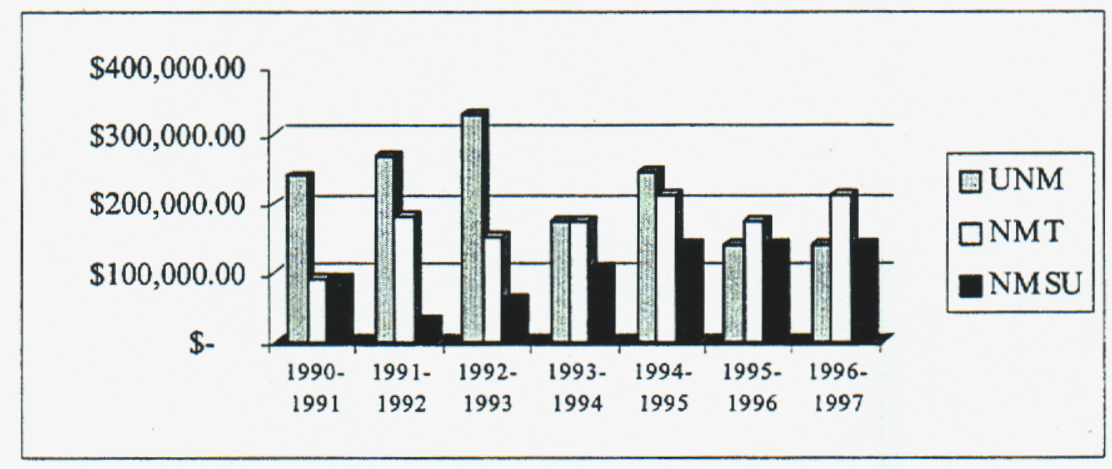

Figure 1. Annual Total SURP Funding 1990-1997

As a program targeting university communities proximate to $\mathrm{SNL}$, the circle of inclusion for SURP stops at the New Mexico border. The University of Texas at El Paso asked to be included in SURP but to date has not been. When asked how important geographic proximity is to fostering interaction with SNL, 53 percent of survey respondents indicated that it was very important. The advances in communication technologies in the past twenty years make collaboration with NMT and NMSU more feasible.

\section{Program Comparisons}

In order to establish a baseline for comparison among SURP and similar programs, the evaluation team examined selected features of early career faculty development programs supported by SNL and six other organizations. Three relevant differences discovered among the other early career funding programs and SURP are: (1) proposal preparation requirements; (2) award value; and (3) eligibility time period. Regarding the proposal preparation requirements

\footnotetext{
${ }^{1}$ Telephone interview with retired SNL vice president, October 1997.

${ }^{2}$ Telephone interview with retired SNL administrator, March 1997.
} 
and the amount of the awards, the other programs at federal agencies are national in scope and competition, raising the ante and necessitating more rigorous standards. The Office of Naval Research, for example, makes approximately 18 early career awards each year, less than 10 percent of the Young Investigator Program submitted proposals ${ }^{3}$. Of the 30,000 proposals NSF receives for all its funding programs, it funds $9,000 .{ }^{4}$ NASA grants only two early career awards per year ${ }^{5}$. As shown in Table 1, the eligibility period for other early career programs is the first five years of tenure-track appointment. Additional information on the eligibility time period is presented in the section titled Award Eligibility.

In fiscal 1997-1998, Los Alamos National Laboratories (LANL) ${ }^{6}$ issued the first call for NUCOR, a new funding initiative for collaborative research conducted at universities in New Mexico. In addition to UNM, NMSU, and NMT, NUCOR accepts proposals from a fourth university, New Mexico Highlands University (NMHU). Each institution is limited to submitting four new NUCOR proposals per year. NUCOR research projects are collaborative efforts between LANL and university investigators, not laboratory-mentored university projects. Although junior faculty are encouraged to apply to NUCOR, all faculty are eligible. NUCOR awards are $\$ 55,000$ and can be renewed twice, for a total of three years of funding. NUCOR subject areas are expected to change with each proposed cycle. Instead of overhead, NUCOR pays an administrative fee not to exceed $\$ 5,000$, an effective overhead rate of 10 percent or less. In NUCOR's first year of operation, it funded only one project.

One final difference exemplifies the disparity between the organizational cultures of the two national laboratories. The NUCOR funding cycle follows the academic calendar while the SURP funding cycle follows the federal government fiscal year. LANL, managed by the University of California, reflects its academic orientation by being more supportive of basic research and functioning more like a university laboratory. SNL is managed by LockheedMartin Corporation. Reflecting a corporate orientation, SNL resembles an industry laboratory in having a narrower focus of research, engineering a product, and controlling research output.

\footnotetext{
${ }^{3}$ Young Investigator Program announcement. Office of Naval Research. http://www.onr.navy.mil/ September 1997.

${ }^{4}$ Grant Proposal Guide. National Science Foundation. NSF 98-2. October 1997.

${ }^{5}$ Phone interview with NASA official, October 1997.

${ }^{6}$ When contacted for this study, university relations personnel at Oak Ridge, Lawrence Livermore, and Los Alamos National Laboratories indicated that they do not have funding programs specifically for new faculty.
} 
Table 1. Annual Total SURP Funding 1990-1997

\begin{tabular}{|c|c|c|c|c|}
\hline Award/ Organization & Eligibility & Award Amount (\$) & $\begin{array}{c}\text { Duration/ } \\
\text { No. Per Year }\end{array}$ & Subject Area \\
\hline $\begin{array}{l}\text { SURP } \\
\text { Sandia National } \\
\text { Laboratories }\end{array}$ & $\begin{array}{l}\text { 1st year new } \\
\text { science/engineering } \\
\text { faculty at UNM, } \\
\text { NMSU, NMT. }\end{array}$ & $\begin{array}{l}\text { Initial } 35,000 \\
\text { Renew } 35,000 \\
\text { Total } 70,000\end{array}$ & $\begin{array}{l}\text { Initial: one year } \\
\text { Renew: one year } \\
\text { Total: two years/ } 10\end{array}$ & $\begin{array}{l}\text { Align with interests } \\
\text { and direction of SNL. }\end{array}$ \\
\hline $\begin{array}{l}\text { CAREER } \\
\text { National Science } \\
\text { Foundation }\end{array}$ & $\begin{array}{l}\text { Appointed after } \\
7 / 1 / 92 \text {. } \\
\text { Already NSF PI. } \\
\text { Tenure track at } \\
\text { U.S. }{ }^{7} \text { university }\end{array}$ & $200,000-500,000$ & $4-5$ years / 350 (new) & $\begin{array}{l}\text { Most fields of } \\
\text { research. }\end{array}$ \\
\hline $\begin{array}{l}\text { Young Investigator } \\
\text { Program } \\
\text { Office of Naval } \\
\text { Research }\end{array}$ & $\begin{array}{l}\text { Received Ph.D. or } \\
\text { equivalent in } \\
\text { preceding } 5 \text { years. } \\
\text { Tenure track at U.S. } \\
\text { university. US } \\
\text { citizens, nationals, } \\
\text { permanent residents }\end{array}$ & $100,000 /$ year & 3 years / 18 (new) & $\begin{array}{l}\text { ONR priority research } \\
\text { areas, annually } \\
\text { revised. }\end{array}$ \\
\hline $\begin{array}{l}\text { No special } \\
\text { announcement, } \\
\text { National Aeronautics } \\
\text { and Space } \\
\text { Administration }\end{array}$ & $\begin{array}{l}\text { Highest degree within } \\
5 \text { years of award. } \\
\text { Already NASA PI. } \\
\text { U.S. citizens, } \\
\text { nationals, permanent } \\
\text { residents }\end{array}$ & $100,000 /$ year & 5 years $/ 2$ (new) & $\begin{array}{l}\text { Earth, space, solar } \\
\text { system, astronautics, } \\
\text { space technologies. }\end{array}$ \\
\hline $\begin{array}{l}\text { Young Scientist and } \\
\text { Engineer Award } \\
\text { DOE- Defense Awards }\end{array}$ & $\begin{array}{l}\text { Already DOE grant } \\
\text { recipient. In first } 5 \\
\text { years of independent } \\
\text { research careers. } \\
\text { Employed by } \\
\text { academic institution. }\end{array}$ & $\begin{array}{l}\text { Amount determined by } \\
\text { DOE institution. }\end{array}$ & $\begin{array}{l}\text { Commitment of } 5 \\
\text { years of funding / } 12\end{array}$ & $\begin{array}{l}\text { Contribution to DOE } \\
\text { national security } \\
\text { mission. }\end{array}$ \\
\hline $\begin{array}{l}\text { R01 } \\
\text { National Institutes of } \\
\text { Health }^{8}\end{array}$ & $\begin{array}{l}\text { Applicant qualified by } \\
\text { participating } \\
\text { organization } \\
\text { (organization often } \\
\text { requires tenure track). }\end{array}$ & $\begin{array}{l}\text { No cap / range from } \\
50,000 \text { to } 1 \mathrm{M} \text { for one } \\
\text { year. }\end{array}$ & $\begin{array}{l}\text { Range 3-5years } / \\
\text { number awarded in } \\
1997=1,480 \text { (new) }\end{array}$ & $\begin{array}{l}\text { Distinct research } \\
\text { endeavor. }\end{array}$ \\
\hline $\begin{array}{l}\text { Early Career } \\
\text { Development Awards } \\
\text { American Federation } \\
\text { for Medical Research }\end{array}$ & $\begin{array}{l}\text { First } 5 \text { years of tenure } \\
\text { track appointment. } \\
\text { Age }</=45.80 \% \text { or } \\
\text { more time to research. } \\
\text { No other grant }> \\
\$ 45,000 \text {. Member } \\
\text { AMFR }\end{array}$ & $15,000 /$ year & 3 years / one & $\begin{array}{l}\text { Research complements } \\
\text { overall program of } \\
\text { research, teaching, and } \\
\text { clinical medicine. }\end{array}$ \\
\hline
\end{tabular}

\section{Award Amount}

The current amount of each individual SURP award is $\$ 35,000$ per year, renewable once for a total of $\$ 70,000$. SURP makes approximately 10 awards each year. The average rate of growth in total SURP awards is 4 percent for the 1990-1997 time period as shown in Figure 1. Seventy-

\footnotetext{
${ }^{7}$ Institutions in United States, its territories or possessions, or the Commonwealth of Puerto Rico that award a baccalaureate or advanced degree in a field supported by NSF.

${ }^{8}$ FIRST awards for new investigators were phased out as of February 1998. An NIH official indicated that $\mathrm{NIH}$ will continue to set aside approximately the same number of awards for new investigators under the R01.
} 
seven percent of survey respondents rated the award amount as adequate to get research started. Eighty-seven percent would not decrease the number of awards in order to increase the award amount. One comment from this group: “...the greater diversity achieved with greater numbers is important, if these are seed grants - a greater number of grants means more seeds and more growth".

Several respondents did note, however, that for many disciplines, the amount of the award necessitates the procurement of matching funds in order to conduct research. One respondent stated that the amount should be evaluated periodically to ensure it is sufficient to pay for one graduate student and one faculty member's summer salary. Another suggested that perhaps a mix of large and small awards could compensate for differences in funding needs.

Reflecting concern that the amount of the award that recipients have use of is too low, approximately two-thirds of respondents indicated that university overheads should be reduced. The recommended changes included a reduction to 26 percent or the current rate for other federal agencies, a flat rate, or elimination. Approximately one-quarter of respondents believed no change was necessary.

The current university overhead rates are:

- UNM: 47 percent (effective July 1, 1998);

- NMSU: officially 41 percent (negotiated rate for four projects in recent cycle was 10 percent); and

- NMT: a flat fee of $\$ 3,500$ per award.

\section{Award Eligibility}

Currently, new faculty in the following disciplines at UNM, NMSU, and NMT are eligible to apply for a SURP grant in the first year of their university employment. Additional academic disciplines are eligible to the extent they are compatible with the current SNL research interests.

\begin{tabular}{ll} 
Sciences & Engineering \\
\hline astronomy & aeronautical \\
biology & chemical \\
chemistry & civil \\
computer science & computer \\
earth and planetary sciences & electrical \\
mathematics and statistics & engineering technology \\
physics & manufacturing \\
& materials \\
& mechanical \\
& nuclear \\
petroleum
\end{tabular}

When queried about the possibility of expanding SURP to include all professors, 82 percent of the respondents preferred to keep eligibility limited to newly hired professors. Ninety-one 
percent of survey respondents indicated that SURP grants should be renewable, with 17 percent advocating one renewal, 45 percent suggesting two renewals, and 38 percent recommending three renewals. Ninety-one percent of respondents also stated that the eligible time period for proposal submission should be extended to the first two years of employment. Some reasons stated for the longer time period include the time required to adjust to life as a university professor, and the conflict in the timing of the SURP funding cycle and the selection of new faculty - often they are not selected in time to meet the proposal submission deadline that occurs prior to their arrival in New Mexico.

\section{Application and Selection Procedures}

SURP applications include four required elements: (1) description of the proposed research; (2) identification of a contact or collaborator at SNL; (3) discussion of how the research project is aligned with SNL interests; and (4) project budget. Fifty-eight percent of survey respondents indicated that this amount of preparation matches the funding received. Two respondents argued for shortening the proposal to one page, making it brief and to the point.

The request for proposals is issued by SNL in March. The universities issue a call to their departments in April. The proposals are due to the respective university review boards in June. The proposals selected by the university review boards are then submitted to the SNL SURP review committee by July 1 . The SURP committee selects the projects and informs the universities, usually in August, in time to permit initiation of contract work by October 1. The award period is from October 1 of the award year to September 30 of the following year.

\section{Scientific Competence}

SURP recipients and SNL contacts rated each other's methodological and analytical ability. Methodological ability refers to the researcher's technical competence - do they know the mechanics of conducting research? Analytical ability refers to the researcher's reasoning capacity - can they interpret the research results? Table 2 shows the respective rankings. 
Table 2. Ratings of Methodological and Analytical Ability

\begin{tabular}{|l|c|c|c|c|c|c|c|c|}
\hline & \multicolumn{4}{|c|}{ Methodological Ability } & \multicolumn{4}{c|}{ Analytical Ability } \\
\hline & Low & Medium & High & Excellent & Low & Medium & High & Excellent \\
\hline $\begin{array}{l}\text { SURP recipients' } \\
\text { ratings of SNL } \\
\text { contacts }\end{array}$ & 0 & 0 & 3 & 8 & 0 & 0 & 4 & 7 \\
\hline $\begin{array}{l}\text { SNL contacts' } \\
\text { ratings of SURP } \\
\text { recipients }\end{array}$ & 0 & 1 & 7 & 6 & 0 & 0 & 7 & 7 \\
\hline
\end{tabular}

When asked how satisfied they were with the conduct of the research project, 91 percent of SURP recipients and 71 percent of SNL contacts expressed high satisfaction. Overall, the majority appear to hold their partners' scientific competence and research work in high esteem.

${ }^{1}$ One recipient felt he had had too little contact to make an assessment.

${ }^{2}$ SURP projects often have more than one SNL contact. 


\section{PART II: RESEARCH OUTPUTS}

The twelve research projects in this study made progress toward their stated research purpose. Sixty-four percent answered the research question and 36 percent made some progress toward a conclusion. The respondents provided the following comments on their progress.

- We made substantial progress on the research question.

- Research question answered. The effects of atmospheric turbulence were quantified.

- I would say we made moderately good progress.

- We accomplished the goal. We proved it could be done.

- Some progress on research question.

- Made some improvement.

- Research questions were answered.

- At the end of the first year, there had been some pretty good progress made.

- We showed a theoretical basis and completed a proof of concept.

- Met milestones of the revised project.

- The goal wasn't quite reached - we were close.

- We accomplished the goal.

Table 3 shows the quantifiable research outputs generated by these 12 projects. Of particular note are the thirty-five new publications. In addition, one project made the following discovery:

- Identified previously unidentified supernova explosion remnants in galaxies, a group of 40 not seen before.

Table 3. Research Output

\begin{tabular}{|l|c|c|c|}
\hline \multicolumn{1}{|c|}{$\begin{array}{c}\text { Type of } \\
\text { Research Output }\end{array}$} & $\begin{array}{c}\text { Number of Projects } \\
\text { Reporting Output }\end{array}$ & $\begin{array}{c}\text { Average } \\
\text { Output per Project }\end{array}$ & Total \\
\hline $\begin{array}{l}\text { Science or technology } \\
\text { problems solved }\end{array}$ & 7 & 0.48 & 7 \\
\hline New publications & 10 & 1.50 & 35 \\
\hline $\begin{array}{l}\text { Incremental product } \\
\text { improvements made }\end{array}$ & 3 & 0.33 & 4 \\
\hline New processes & 4 & 0.75 & 5 \\
\hline New devices & 2 & 0.50 & 2 \\
\hline $\begin{array}{l}\text { Algorithms/software(not } \\
\text { copyrighted) }\end{array}$ & 6 & 1.67 & 14 \\
\hline New patents & 1 & 1.00 & 1 \\
\hline
\end{tabular}




\section{PART III: RESEARCH IMPACTS}

\section{Student Impacts}

SURP recipients and SNL contacts frequently commented that the SURP money was for student salaries. The use of students in research projects requires that SURP recipients not only have the scientific know-how and technical expertise to design and implement the research, but they must also have skills in personnel selection and supervision to successfully complete their project.

All of the projects in this study employed students. Table 4 indicates the number of students who participated in the 12 research projects studied. Student contributions included: (1) completed useful library research; (2) conducted experiments or tests; (3) wrote software; (4) conducted data analysis; (5) wrote papers; and (6) made presentations. Of the twelve projects studied, nine SURP recipients indicated that students contributed to the writing of papers for publication. Of these nine, six made unqualified statements and three qualified their statements about the students' writing contribution with descriptors such as "a little bit" or "first draft."

Table 4. Student Participation

\begin{tabular}{|l|c|}
\hline \multicolumn{2}{|c|}{ Student Participation in 12 Studied Research Projects } \\
\hline Academic Level of Student & Number of Students \\
\hline Undergraduate & 7 \\
\hline Graduate & 17 \\
\hline Post-doctoral & 1 \\
\hline
\end{tabular}

For the projects in this study, 92 percent of the respondents stated that the students made substantial contributions to the projects. All of the respondents believed that participation in SURP was very beneficial to the students' education and training. One student participant in the SURP program now works for Argonne National Laboratories (ANL). Phillips Laboratories, LANL, and SNL hired other students who gained early experience through the SURP program.

\section{Environmental Impacts}

The majority of the projects studied did not report any initial or subsequent methods, products, processes, or other outcomes that increased or decreased air, water, or soil pollutants or hazardous wastes. However, two projects reported that:

- ...whole project was about this. It hasn't been put into practice yet. No funding yet.

- What we did do in later work is develop material used in air and water pollution and hazardous waste sensors and detectors. It may have some commercial value. Sandia is looking at patenting some of that work.

\section{Health Impacts}

The majority of the projects studied did not report any initial or subsequent methods, products, processes, or other outcomes that increased or decreased workplace accidents, hazards, mortality, longevity, or quality of life of the general population. Two projects anticipate the possibility of an increase and a decrease, respectively, in workplace accidents. 
- The first product was actually a very cheap imaging device for infrared lasers. For people using it for lasers, it contributed to an increase in accidents, maybe. Can't quantify potential increase.

- It comes back to chemical sensors and we've been working and continue to work on materials that can be used for detection of hazardous chemicals either in the workplace or anywhere else. So, for example, we had a small grant from Los Alamos after the SURP started where they were being funded from a consortium of companies that produced textiles. Textile factories have high levels of solvents in the air and they wanted to be able to detect solvents because for one thing, it's bad for the worker to breathe and also, if the levels get too high, they get explosive. Concentrations can be high enough to be explosive.

Two other projects had the following comments regarding the impact on quality of life.

- I think there will be an impact in the workplace and work satisfaction and the quality of life for the general publication. Through the use of virtual reality technology, we're really improving and studying the human/computer interface. By doing so, the hope is we will improve peoples' ability to do work on computers. We're studying different aspects. SURP contributed along the way. SURP helped us study this sort of thing. We are learning about how to interface people physically and psychologically for safety and effectiveness on computers. I can't really gauge the extent of the impact, it's hypothetical right now because it hasn't moved out of the laboratory into the workplace very much, but the potential is extremely big, but it's hypothetical. A number of groups across the country are doing the same thing.

- Well, theoretically, we're always trying to develop processes to increase the quality of life, but no direct effect.

\section{Economic Impacts}

When SURP recipients were asked about any initial or subsequent methods, products, processes, or other outcomes that increased or decreased businesses or employment opportunities, they saw the potential for the following economic impacts from their work.

- Not yet. Potentially commercializable.

- I think it will. It hasn't, but it should. People will be doing engineering and science differently, and actually manufacturing, too.

The research projects identified the following industries as potential users of the generated research outputs:

- infrared-emitting lasers;

- aerospace;

- computer design;

- manufacturing;

- telecommunications;

- healthcare;

- advanced materials;

- earthquake monitoring; 
- mining; and

- the general scientific community.

\section{Principal Investigator Career Impacts}

When asked why they received a SURP contract and others did not, the SURP recipients cited several reasons, many showing that the university researchers understood the importance of alignment with SNL interests.

- I don't know why they were turned down. I think mine was accepted because it corresponded to an area that the lab was working in.

- I don't know. Great title, I guess. I don't know. Maybe because the stuff was more relevant to their needs. I don't really know what other people submitted.

- I actually don't know. The reason I'm hesitant about that is that I don't know how competitive it was. My guess is that unsuccessful proposals may not have been well prepared or there was not an even cursory match with Sandia interests. My guess is the latter is probably the biggest reason.

Others SURP recipients believe that the quality of the science or plan of research might have been the determining factor.

- I hope it was because I had a good proposal and because I had contacts at Sandia and a real plan for working with them. Looking at the people who do not get funded, the problem is usually they don't have a plan. We had a very definite scope.

- Maybe because I know how to write good proposals. I know how to express research plans that are believable in terms of being able to solve the research problems.

- Ingenious project.

- Work plan - confidence.

- Good science, presentations, important subject matter.

- We had a patent pending. We had demonstrated this to a lot of people. We had gone to a lot of different groups and Sandia was one of the groups. We approached Sandia probably in 1993 or so about this idea, that we might be able to do this. We also approached integrated circuit manufacturers. Sandia was the only one who really said "Well, maybe." They kept looking at us and then they approached us and asked us independently to perform a test just to see what we could do, and that was about six months before the SURP proposal. Allan Ryder and another gentleman from Sandia came down and we ran the test while they were here. We got the results while they were here, so they had full control over the test. We showed them excellent results during that time. So previous to funding, we had already demonstrated to Sandia that the technology looked like it worked based upon everything we had claimed. So, they basically screened us before we went in. So, I would say the reason why we were successful the first year was because Sandia had already pre-screened us. It wasn't a matter of us just sitting down and talking with them about an idea. We had already talked with them about the idea and then they said "Okay, now, try it. Let's give you a small test to see what you can do." In fact, we ran two separate tests, had success. So they said there must be something there, and I think that's what convinced them. 
Others speculated about the timing of the proposal preparation and influence of interested SNL contacts.

- Wrote proposal before I came.

- Some feel it was cut before I got here. It came with the job.

- I don't know, can't answer question; committees decide. It probably had to do with Sandia contact.

- I can't really say why others did not. I didn't know the competition. I think that probably at the time the commitment by the Sandia contact for this area of research, also I believe I put together an unbelievably good proposal.

Once they received the contract, the SURP recipients identified the following career impacts.

- A good impact. It helped very much in supporting me, supporting a graduate student, which helps indirectly, obviously. Getting a publication. Travel.

- It certainly was beneficial. It generated something like a dozen grants largely from NASA. It was planned to gain expertise in the field. That was desirable from the point of view of NASA. I'm still working on those projects today.

- It certainly was very helpful to have that funding when it came. So I would say that it allowed me to hire students to do work at a very appropriate time, early in my academic career. So it kind of leveraged stuff I was trying to do.

- Turns out it's had a big impact on my career. I told you my standing was assistant professor, I just learned that my tenure to associate professor has been approved.

- Positive, good start.

- Assisted in getting tenure.

- Good start. First grant after I came. Good opportunity to collaborate.

- It was very helpful because it helped me to solidify research associations. That's what the professional development side of my work out here has been about for the last two years.

- Progressed. Helped.

- It certainly helped me get started. We were able to get some work done and publications. Because we had some early productivity, it helped me be more competitive when I was going out for external funding.

- It provided the opportunity to do things. The work is more interesting.

SURP recipients have received the following awards.

1980-1984 Regent Scholarship winner

KERAMOS Honor Society Ceramic Engineers

1987-1991 Eastman Kodak Fellowship Recipient

1995-1996 Graduate Teacher of the Year

1992-1995 Regents Lecturer

1993-1994 International Scientific Exchange Award, NSERC, Canada

1983-1984 Ontario Graduate Scholarship

1981-1983 NSERC Postgraduate Scholarship

1980-1981University of Toronto Connaught Scholarship

1979 Royal Astronomical Society of Canada Gold Medal 
1975-1979 Ford Motor Company Scholarship

1975 University College Bursary

1996 SRC [Semiconductor Research Corporation] Inventor Recognition Award

1992 SRC [Semiconductor Research Corporation] Award for Technical Excellence

1987-1988 AWU Fellowship, SNL

1984-1986 Presidential Professorship, UNM

1969-1972 NDEA Fellowship, Michigan State University

1966 Leadership Scholarship, University of Wisconsin

1965 Legislative Scholarship, University of Wisconsin

1996-2000 NSF Faculty Early Career Development Award, UNM

1996 Outstanding University Inventor Award, SRC

1992-1993 Ford Foundation Postdoctoral Research Fellow, Harvard University

1991-1992 NIH Postdoctoral Research Fellow, Harvard University

1985-1986 Kaiser Aluminum Graduate Fellow, University of Washington

1993 Eugene Wigner Fellow, ORNL

1988 Materials Research Society Graduate Student Award

1988 American Vacuum Society Student Award

1983 Sage Fellowship, Cornell University

1992 Certificate of Recognition NASA Class I NASA Tech Brief

Tau Alpha Pi National Honor Society

SSA Best paper

Dissertation prize - Annual prize, best Ph.D. student in math

UNM General Library Knowledge Award for Outstanding Work

Fifty percent of the SURP recipients reported that they were more successful in regard to tenure and promotion than other members of their university cohort. Seventeen percent said that they were very successful, and 25 percent said they were equally as successful ${ }^{1}$. Nearly three-quarters of the SURP recipients perceive that this program translates into their increased marketability for jobs or grants.

Five of the twelve SURP recipients reported receiving a total of $\$ 70,000$ from SNL through the SURP program for their research projects. The total SURP funding received by the other recipients ranged from $\$ 30,000$ to $\$ 75,000$, reflecting the variability of award amounts in the past. Table 5 indicates the follow-on funding generated by ten of the twelve SURP research projects studied (two of the SURP projects did not generate follow-on funding).

${ }^{1}$ One declined to answer the question. 
Table 5. Subsequent Research Grants/Contracts/Projects Resulting from SURP Research. Listed by Follow-on Funding Source

\begin{tabular}{|l|c|c|}
\hline \multicolumn{1}{|c|}{ Source } & Amount (\$) & $\begin{array}{c}\text { Duration } \\
\text { (years) }\end{array}$ \\
\hline Sandia National Laboratories & 4,000 & 1 \\
& 5,000 & 1 \\
& 22,000 & 1 \\
& 29,000 & 1 \\
& 30,000 & 1 \\
& 30,000 & 1 \\
& 34,000 & 1 \\
& 35,000 & 5 \\
& 42,000 & 0.25 \\
& 60,000 & 1.5 \\
\hline Los Alamos National Laboratory & 100,000 & 5 \\
\hline Department of Energy & 15,000 & 1 \\
\hline UNM Industrial Center & 150,000 & 3 \\
\hline NMSU Physical Science Laboratory & 100,000 & 1 \\
\hline Air Force Office of Science Research & 22,000 & 1 \\
\hline Boeing, Inc. & 60,000 & 1 \\
\hline National Science Foundation & 30,000 & 1 \\
\hline & 185,000 & 3 \\
& 216,000 & 3 \\
\hline Natl. Aeronautics \& Space Admin. & 219,000 & 2 \\
\hline & 378,000 & 5 \\
\hline & 112,000 & 3 \\
\hline
\end{tabular}

\section{University Department Impacts}

Thirty-nine percent of university respondents perceived that association with the SURP program influenced or improved departmental research. Twenty-two percent believed that the program influenced curriculum. Eighteen percent identified increased department collaboration and connections with SNL. Three respondents also noted an impact on individual faculty research and the attraction of better caliber students to their departments through SURP participation. Specific comments concerning departmental impacts included the following.

- Research and courses offered. Sandian taught course at NM Tech one year - very good for students.

- More affiliations with SNL. Track, focus, mission, research, curriculum, courses offered, training offered. All of the above. Interaction of faculty with SNL - applies to all aspects of faculty work. 
- Sensitive to research programs at SNL. Over last 12 years, adjusted programs (academic) and research to reflect SNL interests.

- I think it clearly has had an impact on - probably not much of an impact on the curriculum, per se, but it has had impact on the research direction of the college.

- The existence of whole disciplines within the unit evolved as result of SURP.

- Increases early development of research careers of new faculty - enhances research production of new faculty. Emphasis on fields of technology which SURP supports is mutually beneficial to the university and SNL.

- Sandia has had a lot of influence on the research direction, particularly - now we're doing some work in security and human biometrics, and I don't think that would have happened without Sandia's support. So, I think Sandia has a lot of effect on the research focus of the department. The other thing, the contacts that we've made with Sandia have been important and they're long-lasting. We're in the process of redoing the curriculum to meet the new requirements, engineering accreditation requirements for 2000, and our technical contacts with Sandia are helping us with this. They are active in advising how they feel the curriculum should go. So, it's been a big help in that regard. So, I think those two things, the research focus and the curriculum, are strongly influenced.

- It's had a big impact on the department. Most of the people that come via the SURP program get to know people at Sandia, and that's a positive enhancement on the research side because just interactions help. The money; it all has been very good for the department.

- Because of this we now offer a course down here periodically in integrated circuit testing, and that's probably 100 percent directly related to the fact that Sandia sponsored it and gave it some credibility. And, we participated in a joint course last fall that was run out of UNM; it had a lot of Sandia people as well as other people from the industry and we also contributed.

Regarding the influence on faculty recruitment, 76 percent of university survey respondents reported that SURP has impact. The twenty-one percent who reported that it did not may be reflecting the variation of involvement in recruitment (junior faculty are not as involved), the differences in probability of receiving funding between disciplines, and the increased competitiveness within the program. The difference in perception regarding the likelihood of funding is shown in the following three comments.

- I don't think it has any. What are you going to do? Come and tell a person he can apply for a grant and maybe get turned down? Sandia's more of an engineering facility than basic research, so in engineering I think there's a lot closer tie that can be made. But when you come into the other fields, especially things like astronomy, where I don't know if Sandia even has a few astronomers on staff, it's harder to make a connection with people. But we have had a history. I've had one. There are eight of us, so half the department has had one of these even though it's not in a field in which Sandia has a large stake.

- It is nice because it is a pretty high probability for a new faculty member. The department can use that fact as a sort of augmentation of the start-up package.

- I think people understand that it's an opportunity. However, they know it's competitive, so they approach it as not a sure thing. It's an opportunity, you might get this but you may not. I know that last year there were maybe seven or eight new faculty members who applied and 
because of that, there weren't that many slots available, so they all went away kind of disappointed. I think it really has to fit in with Sandia's mission.

One respondent mentioned that because New Mexico is a poor state, the resources available to science institutions are limited. This enhances the importance in recruitment of funding opportunities like SURP. Additional comments reflecting the importance of SURP to faculty recruitment included the following.

- The thing that came first to mind for me is that we think that it helps us recruit new faculty in that we, when we interview a faculty member in chemistry, we try to have them stay on the interview an extra day and have them talk to Sandia people, and we use the SURP program as leverage to get them to participate. It is fairly high probability of funding for a young person.

- Faculty recruitment. Very good, is a plus. Physics new professors came because of SURP. Apply before come - incentive to receive and help psychologically to get going.

- I think it does have an impact there. When I interviewed for the job, I was pleased to learn that there was an immediate path for collaboration. So, a significant effect.

- It helps a lot. We've been able to attract some really, what I would consider, top-notch young faculty and just recently we've had a lot of retirements and in the last three or four years we've had a lot. Over half of them have received Sandia SURP.

- We in chemistry have consciously tried to use it as much as we can. It's something we think is a competitive advantage for us that other places don't have.

The affiliation with SNL also influences student recruitment, as evidenced in these comments.

- Well, as far as the SURP program itself helping recruit graduate students, I know that just yesterday there was a student in here who was already accepted to a number of very good schools, but he was still looking at us because of our interaction with the national labs. So there are students who are interested in New Mexico because of the proximity of the labs and of course this is a direct tie to the labs.

- We do have other types of collaboration with the labs in the way of visiting scientists. They give seminars down here and there are other collaborations that go on that are non-SURP. So, it's part of the puzzle there. For student improvement we do make a point of telling potential students that we have some collaboration with Sandia on down the line.

- Students who are interested in certain kinds of chemical research, for example, materials research or analytical problems, those kind of people here have interactions with Sandia scientists. Students appreciate that that might open doors to further opportunity that they might not have elsewhere.

- I kept reminding my students who this was in collaboration with. When they went for job interviews and when they talked to people about Sandia, I think it gave them a lot of credibility. So, I think from the student's point of view, when they went to interview, I think that made them look a heck of a lot better, just because of their association with Sandia.

- It helps graduate student recruitment, because any time you have funding where the professors can support a graduate research assistant, that helps your recruiting. So, it's definitely a good tool. Some of the guys have hired undergraduate research assistants, but I 
don't believe the SURP goes for that directly, but it frees up other funds. It does open the doors for a few undergraduates, but not nearly as much as for the graduate program.

The disparity between the academic cycle and SURP cycle may also impact student recruitment.

- I was able to retain some graduate students who may have gone off earlier with SURP funding. I would think I would say not so much in recruitment but in retention. The problem is that students apply long before you know you have funding. The synchronization of the funding approval and the students being admitted into the program are not well organized. You have to know long in advance, almost a year in advance, before you can get a student to count on.

The question of whether the SURP program is mentioned in printed recruiting materials for the academic unit brought negative responses from 50 percent of the respondents, positive responses from 36 percent, and 14 percent were unsure. Since SURP supports graduate students and results in new classes being offered, 46 percent said that SURP has a positive impact on credit hour generation of their academic unit.

University survey respondents said the following four factors contribute to the ranking and stature of academic units: (1) quality of faculty; (2) number and size of grants; (3) organizational affiliation; all of which result in (4) greater visibility. Twenty-nine percent of the respondents cited recruiting and developing faculty as the indirect influence SURP has on academic ranking. Twenty-one percent noted that the greater number of grants generated as a result of SURP contribute to the ranking of the department. The reputation enhancing impact of affiliation with SNL was cited by 14 percent, and 25 percent felt the cumulative impact of SURP participation causes greater visibility, which ultimately establishes unit rank and stature. The comments included:

- Very significant. UNM moved to the top $3^{\text {rd }}$ or $4^{\text {th }}$ in the country in some aspects of materials science due to some UNM people who got support. UNM materials science SURP recipients are highly cited, according to Chuck Meyers.

- It helps. We're ranked above UNM in that regard, and we're fairly well ranked in the regional universities, and I think our Sandia association has been very important to that. I think that's very significant.

- Like every grant, it's always a huge help. I think one of the things that it did most recently, one of the people we supported was able ultimately to get an NSF career grant as a result of the preliminary SURP support. I think that was helpful to him and probably to the department as well. These career grants are very competitive and hard to get. There's no question that having that start-up money from SURP is an enormous help.

- Oh, it looks good, it does. Just to tell people that you're tied in with Sandia is a big feather.

Respondents identified participation in SURP as a contributing factor in the development of the following six research centers at New Mexico universities.

- Center for Micro-engineered Materials (CMEM), which is an NSF center;

- Center for High Technology Materials (CHTM); 
- Electron Vision Analysis Laboratory;

- Center for Space Telemetry and Telecommunications;

- a 400 megahertz NMR facility; and

- the Optics Laboratory.

Finally, 100 percent of the university respondents reported that continued contact with SNL is very beneficial for New Mexico universities.

\section{SNL Impacts}

SNL respondents identified four benefits that SNL receives from SURP: (1) increased understanding in the subject matter explored by the projects; (2) exposure to unique research areas; (3) cost-effective research; and (4) collaborative relationships between SNL and New Mexico university faculty. In concert with the purpose of SURP (to acquire fundamental knowledge), 77 percent of respondents identified increased SNL understanding as a SNL benefit. Two respondents noted that the project work was unique, another two that collaborative relationships were established, and two more that the research was a cost-effective investment. One hundred percent of SURP recipients and SNL contacts said that the research conducted under SURP would have cost SNL from two to fourteen times as much for the same results had SNL not received the university participation. Seventy-five percent perceived the outputs of the SURP projects studied to have application for Defense Programs. Respondents' estimates of the applicability of these research outputs to Defense Programs are shown in Table 6.

Table 6. SURP Project Outputs Applicable to Defense Programs

\begin{tabular}{|c|c|c|c|c|}
\hline $\begin{array}{c}\text { Percent } \\
\text { Applicable }\end{array}$ & $\begin{array}{c}\text { Number of } \\
\text { Projects }\end{array}$ & $\begin{array}{c}\text { Percent of } \\
\text { Projects }\end{array}$ & $\begin{array}{c}\text { Cumulative } \\
\text { Frequency }\end{array}$ & $\begin{array}{c}\text { Cumulative } \\
\text { Percent }\end{array}$ \\
\hline 0 & 2 & 10.0 & 2 & 10.0 \\
\hline 10 & 1 & 5.0 & 3 & 15.0 \\
\hline 20 & 1 & 5.0 & 4 & 20.0 \\
\hline 30 & 2 & 10.0 & 6 & 30.0 \\
\hline 50 & 4 & 20.0 & 10 & 50.0 \\
\hline 60 & 1 & 5.0 & 11 & 55.0 \\
\hline 80 & 1 & 5.0 & 12 & 60.0 \\
\hline 90 & 2 & 10.0 & 14 & 70.0 \\
\hline 100 & 6 & 30.0 & 20 & 100.0 \\
\hline
\end{tabular}

The following are comments about the benefits SNL derived.

- Well, I guess it enhanced the level of understanding in an area they are very interested in that is, ceramic and electronic materials. To basically develop new protocols for synthesis for ceramic and electronic materials.

- I think we have essentially opened up a broader research area for them in the area of human/computer interface issues. I think we have helped them understand how important it is to the kind of mission Sandia has. Particularly in the future when they're doing more of the strategic computing type work that they're starting to do now.

- Help fulfill their responsibility regarding nuclear proliferation. 
- It actually turned out to be of considerable benefit because of the recent stress on computer modeling. That's really what's caused so much interest and has led to a project lately. We already had the model in hand and had been working on it for a couple years.

- They were interested in infrared detection, but they also saw it as potentially a way to build some safeguards into copying equipment, in that you could put some of these up-converters in paper and they would be excited by special copiers so you wouldn't be able to copy the document. I don't know whether they ever pursued that or not, but that was one thing they were thinking about. They had some sort of fundamental interest in infrared detection for safeguarding documents. Whether they ever did anything with it, I don't know.

- It extended our manpower capabilities.

- We have used some of the techniques that he put into his code. It was beneficial and we also have a contact and can get some longer-term pay-off if we need additional expertise in this area.

- It added to our field of expertise.

- It established collaboration between the image processing facility at SNL and the Institute of Astro-Physics at UNM.

- They were able to carry out research in a cost effective way that we would be doing.

SNL contacts understood that they could have access to university facilities to conduct research through SURP projects, but since university facilities are similar to those at SNL, this was not seen as an important benefit to SNL.

In regard to the accomplishment of the program's goals of obtaining needed scientific knowledge and technical expertise and strengthening the university technical community in needed areas, 65 percent of respondents rated the SURP project that they conducted or provided oversight for as well aligned between the universities' and SNL's goals. For SNL contacts, a fairly consistent pattern emerged between the project's alignment with SNL interests and the contact's familiarity with the research project goal and achievement of the project goal.

As discussed earlier, respondents indicated that SNL has received scientific understanding and technical knowledge from SURP projects and, as shown in Table 6,70 percent of respondents estimated that 50 percent or more of the SURP research project outputs were applicable to DOE Defense Programs. The survey also asked which SNL foundation(s)/core competency(ies)/ mission(s) linked to the SURP project (Table 7). SNL contacts found it easier to answer this question than SURP recipients.

Table 7. Linkages of SURP projects to SNL Foundations/Competencies/Missions

\begin{tabular}{|l|c|}
\hline \multicolumn{1}{|c|}{ SNL Foundations/Competencies/Missions } & Number of Projects \\
\hline Materials & 6 \\
\hline Environment & 1 \\
\hline Weapons research & 3 \\
\hline Simulation or modeling sciences & 3 \\
\hline Computer science & 2 \\
\hline Electronic reliability & 1 \\
\hline Geosciences & 1 \\
\hline Engineering science & 1 \\
\hline
\end{tabular}




\begin{tabular}{|l|c|}
\hline SNL Foundations/Competencies/Missions & Number of Projects \\
\hline Molecular modeling & 1 \\
\hline computations & 1 \\
\hline
\end{tabular}

LANL, in its new program NUCOR, identified specific areas of research in which it will accept proposals. While this approach begins to address the alignment issue, it may not enable applicants to successfully align with LANL interests. SURP is currently providing SNL's core competencies and research foundations to universities in its call. The call could be expanded to include the missions of both SNL and DOE to augment the boundary identification. The next step after identifying boundaries is to train university researchers to function within those boundaries. In a 1997 paper, Falcone and Bjornstadt ${ }^{2}$ provide a step-by-step method to enable the bench-level scientist or engineer to acquire these skills.

One final point is necessary regarding the alignment issue. To maximize the benefit in the longterm for both SNL and the universities, the alignment of SURP projects with the interests of SNL must be understood as an on-going process rather than a hurdle that is overcome with the acceptance of the research proposal. This alignment occurs in the context of a research partnership and, as with any relationship, requires continual communication to remain vital.

\section{Statewide Impacts}

Eighty-six percent of survey respondents perceived that the overall impact of SURP on the state of New Mexico is positive. Seven respondents specifically mentioned positive economic impact through the contribution the funding makes to the New Mexico economy. They noted that because the universities' faculties are strengthened, they are more capable of getting outside funding, thereby bringing more research dollars into the state. Respondents also commented that:

- A great faculty makes a great university.

- There are a lot of things that impact education in New Mexico, but I think you could say SURP directly assists us in obtaining and hiring high-quality faculty. It allows us to maintain a research Category One stature among the top 70 research institutions in the United States, which has got to have a positive impact on the state of New Mexico.

When queried about how they let lawmakers know they have successful interaction with the national laboratories, university respondents indicated that official contact with lawmakers is limited to those in official roles. However, faculty noted that they communicated informally with lawmakers through talking to people in state government and the Board of Economic Development. Faculty members keep their deans informed about research collaborations and the deans talk directly to U.S. senators and representatives about the positive impact SNL has on their university.

${ }^{2}$ Falcone, S. and D. Bjornstadt (1997) "Measuring Public Sector R\&D: Part I", submitted for publication. 
Official communication is made through requested presentations to the State Science and Technology Center, legislative committees, and members of the congressional delegation. In addition, annual reports, brochures, and letters from the universities about research activity and funding sponsors are sent to state elected officials and members of the congressional delegation detailing and highlighting laboratory funding. Those in official roles at the universities stated that they talk to lawmakers in testimony before committees, at legislative appreciation events, and in personal contacts about research sponsors and collaboration with SNL.

If the funding for the SURP program were threatened, university survey respondents said they would encourage those in positions of authority in the university (department chairs, deans of colleges, and vice provosts), their representatives and senators in Congress, and officials at SNL and Lockheed Martin to take the following actions.

- Open up discussion about it.

- Express strong support for SURP.

- Communicate SURP benefits.

- Identify how negative the impact will be on faculty.

- Argue, shout, complain.

In addition, university respondents specifically said that they would:

- Call SNL's president; 2) have president of the university call SNL's president; 3) call congressman - why funding threatened? and have him call SNL's president and then have him call senators.

- talk with university president to talk to president of SNL.

- I think we would call SNL vice presidents who are strong supporters of SURP, and we'd see if we couldn't stop that silly idea.

- I would want to write a letter to the people explaining how useful it was to me as a starting professor as seed money for my program.

- I would do all possible to retain. University, talk to DOE, SNL, legislators.

- 1) Set up meeting. 2) Put on agenda with ongoing meetings with SNL official liaison person. Managed camps approach: discussions with various VPs. 3) Improve or reduce threat. Contact SNL directors, people involved in making research allocations for SNL budget.

- Well, I would talk to my dean and see if he couldn't talk to our members of Congress, particularly Senator Domenici. 


\section{PART IV: PROGRAM IMPEDIMENTS}

In a general sense, there are two categories of impediments to $R \& D$ funding programs, those that block execution of the research and those that block accomplishment of the program's goals. In regard to the execution of the research, Table 8 shows the responses of SURP recipients and SNL contacts to the question: Do any features of the SURP program create impediments to the successful completion of the research?

Fifty-eight percent of respondents indicated that none of the features of SURP create impediments to the successful completion of the research. SURP recipients expressed concern about the restriction regarding the use of SURP money to purchase equipment, noting that new professors are most in need of establishing their laboratories. SNL contacts expressed concern regarding the restrictions on meeting with foreign nationals. Two SURP recipients who did not perceive impediments said that:

- We met once a week. This established our research relationship and led to later collaboration.

- My SNL contract monitor found the equipment I needed and loaned it to me to do the research. I subsequently obtained grants that I used to replace and buy equipment.

Table 8. Program Impediments to Research Completion

\begin{tabular}{|l|c|c|}
\hline \multicolumn{1}{|c|}{ Do any features of the SURP program create impediments? } & $\begin{array}{c}\text { SURP } \\
\text { Recipients }\end{array}$ & $\begin{array}{c}\text { SNL } \\
\text { Contacts }\end{array}$ \\
\hline $\begin{array}{l}\text { Yes, not being able to spend the funds on equipment or having to } \\
\text { return purchased equipment to SNL. }\end{array}$ & 4 & 0 \\
\hline Yes, hard to collaborate from a distance. & 1 & 0 \\
\hline Yes, not being able to pay student's tuition with the funds. & 1 & 0 \\
\hline Yes, clearances required to access SNL facilities. & 0 & 1 \\
\hline Yes, need more emphasis on working closely with SNL. & 0 & 1 \\
\hline Yes, the treatment of foreign nationals. & 0 & 3 \\
\hline Yes, should return overhead to PI. & 0 & 1 \\
\hline $\begin{array}{l}\text { Yes, when need matching funds to do research they are hard to } \\
\text { find. }\end{array}$ & 0 & 1 \\
\hline $\begin{array}{l}\text { Yes, hard to coordinate SURP funding cycle (federal fiscal year) } \\
\text { with students' needs (university fiscal year). }\end{array}$ & 1 & 0 \\
\hline No & 7 & 11 \\
\hline
\end{tabular}

If further collaboration is a long-term indicator of goal accomplishment, then impediments to collaboration may also be impediments to the accomplishment of the program's purposes. Respondents noted that money assisted in developing collaboration as did having an established relationship with the SURP recipient and the "high quality of the university person." The list of factors impeding collaboration is shown in Table 9. 
Table 9. Factors Impeding Collaboration

\begin{tabular}{|l|c|}
\hline \multicolumn{1}{|c|}{ Factors } & Number of Responses \\
\hline Research priority change. & 6 \\
\hline Foreign national issue. & 3 \\
\hline Lack of money. & 3 \\
\hline Program change. & 3 \\
\hline Other research opportunities. & 2 \\
\hline Sandian changed jobs. & 2 \\
\hline Research funding change. & 1 \\
\hline SNL technically oriented, not as supportive of basic research. & 1 \\
\hline University research projects not having relation to SNL work. & 2 \\
\hline
\end{tabular}

Comments concerning further collaboration included the following.

- It's hard to say. I think the thing that impedes collaboration globally is that others are so busy. They're just so busy with other research opportunities. People are working and it's hard for them to get time to do things. Most the stuff people are doing over at Sandia is much bigger than what we're working on here. You know, millions of dollars of funding and that sort of thing. So, it certainly takes their attention away from these little $\$ 35,000$ contracts.

- The biggest thing that probably changed things was other research directions and interests on my part. I mean, we worked on these problems, but then we have done other things as the years have gone by. I still interact quite a bit with people at Sandia and some of my initial contacts you can trace back to people that I met in my first couple years here. Some of those through this contract. Very different people today working on very different problems, but I met those people through people that I met early on through this contract. In that sense, there are still seeds of that early interaction.

- Other proposed efforts are too much originated by the faculty with little tie to actual research at Sandia. We need to find a way to encourage young faculty to steer their work in our direction if they expect follow-on collaboration. 


\section{PART V: EVALUATION SUMMARY AND RECOMMENDATIONS}

Based on the data obtained from the structured interviews conducted for this evaluation, the SURP program is achieving its purpose. From the varied professional perspectives of the respondents, the SURP program is effective in the professional development of new science and engineering faculty recipients at New Mexico's universities. Departments, colleges, and the universities have indirectly benefited as SURP recipients continue in productive academic careers. While the consensus regarding SURP is positive, from each perspective there are improvements that will further enhance the strengths of this program.

Three areas of needed improvement are consistently mentioned: (1) award eligibility; (2) financial considerations; and (3) alignment of research interests. Allowing new faculty a second year of eligibility would enable those faculty who are not recruited with a SURP contract an equal chance at participation in the program. Even for those who are informed of the program prior to relocation in New Mexico, the application period coincides with major life changes (geographical move, starting a research career, and changing from being a student to being the teacher) that could negatively impact the possibility of completing the application. Also, there may be insufficient time to prepare the proposal before it is due since the time span of the contract follows the federal rather than the university calendar.

Raising the total amount awarded could enable either more awards to be made or the individual award to be raised. Also, lowering the overhead rate will make more funds available to the SURP recipient. If adjustments are possible in allowable expenses to include equipment, or if SNL contacts are able to lend or make equipment available for use, the financial stress and startup time lag of obtaining the necessary tools to do the research would be eased. In addition, permitting two renewals would produce a greater return on the already expended costs.

Some educational institutions are not preparing their students for success in the workplace. The actual tasks of research include (1) identifying professional research interests; (2) constructing a research plan; (3) designing experiments; (4) harmonizing professional research interests with funding source interests; (5) writing proposals; (6) collaborating on research; (7) supervising students; (8) teaching; (9) writing up research results for sponsor reports; (10) and writing up research results for peer-reviewed publication. SNL could endeavor to influence universities in New Mexico and other states to implement the proper instruction in $\mathrm{Ph} . \mathrm{D}$. programs in science and engineering to better prepare their graduates for the competitive world of research and development. 


\section{Distribution}

\begin{tabular}{|c|c|c|}
\hline 1 & MS 9018 & Central Technical Files, $8945-1$ \\
\hline 2 & MS 0899 & Technical Library, 9616 \\
\hline & MS 0612 & $\begin{array}{l}\text { Review \& Approval Desk, } 9612 \\
\text { for DOE/OSTI }\end{array}$ \\
\hline & MS 0188 & University Research, 1030 \\
\hline
\end{tabular}

